malate dehydrogenase activity were remarkably strong in all layers of epithelium except the cornified layer. Decreasing activity of the DPN-linked dehydrogenases were noted in the follwing order: lactate, malate, $\alpha$-glycerophospate, glutamate, $\beta$-hydroxybutyrate. And 2 TPN-linked dehydrogenases were less active than DPN-linked dehydrogenases except the $\boldsymbol{\beta}$-hydroxybutyrate dehydrogenase activity. Cornified layer of epithelium showed abundant dehydrogenase activity, on the contrary the most basal layer was remarkably reactive for all dehydrogenases on this study.

On carcinoma nest the dehydrogenase activity was negative in the keratinous pearl of well-differentiated form. It was similar to the cornified layer of normal epithelium. While the activity in the well-differentiated carcinoma nest except the keratinized portion, the intermediately differentiated and the undifferentiated form was similar or less to the activity of stratum germinativum of normal epithelium.

\title{
References
}

1) Monis, B., Nachlas, M. M., Seligman, A. M., Cancer $12: 1238-1247,1959 . \quad$ 2) Deane, H. W., Lobel, B. L., Romney, S. L., Am. J. Obst. \& Gynec. $83: 281-294,1962 . \quad 3$ 3) Lobel, B. L., Deane, H. W., Rommey, S. L., Am. J. Obst. \& Gynec. 83 : 295-299, 1962. 4) Nachlas, M. M., Tsou, K. C., De Souza, E., Cheng, C. S., Seligman, A. M., J., Histochem. 5: 420-436, 1957. 5) Nachlas, M. M., Walker, D. G., Seligman, A. M.' J. Biophys. Biochem. Cytol. $4: 29-38,1958.6$ 6) Nachlas, M. M., Walker, D. G., Seligman, A. M', J. Biophys. Biochem. Cytol. $4: 467-474,1958$. 7) Nachlas, M. M., Course in Histochemistry, June 13 to $18,26,1960$. 8) Herbut, P. A., Gynecological and Obstetrical Pathology, 219-222, 1953.

\section{Histochemical Study of $\beta$-Glucuronidase in the Uterine Cancers}

\author{
Naotaka IshizukA and Minoru IsHiHARA \\ Department of Obstrics and Gynecology Nagoya University, School of Menicine. \\ Hideo Yamada, Ginshiro Nobata and Isawo Chaya \\ Depatment of Obstrics and Gynecology Nagoya National Hospital.
}

\section{Introduction}

As the enzymatic studies of malignant tumors in the biochemical region progress, we want to know the localization of these enzymes. In the year 1934 Masamune observed $\beta$-glucurondase in the kidney of ox and in the same year Oshima observed it in many different animal tissues. In 1947 Fishman found intense activity of $\beta$-glucuronidase in cancer tissues. It has been sugge- 
sted that the $\beta$-glucuronidase may have three functions in the body; (1) the conjugation of steroid hormones, (2) the hydrolysis of conjugated glucuronides and (3) participation in cellular proliferation.

In our series, the localization of $\beta$-glucuronidase in cancer tissues of uterus was observed after the method of Seligman, Tsou, Rutenberg and Cohen.

\section{Materials and Method}

All specimens were obtained surgically from 60 patients and stored immediately in a dry ice pot. The age of these patients was ranged 27 to 65 and the clinical stage of the cervical cancer comprised 0 to 3 stage. Frozen sections of $20 \mu$ in thickness were prepared in a cryostat according to Coon's modification of the Linderström-Lang tenchnique and incubated at $37^{\circ} \mathrm{C}$ for 6 hours in the substrate. The substrate was prepared by dissolving $15 \mathrm{mg}$. of the substrate, 6 -bromo-2-naphthyl- $\beta$-D-glucuronide, in $2.5 \mathrm{ml}$. of methanol followed by the addition of $10 \mathrm{ml}$. of Mcllvaine-Lillie buffer ( $\mathrm{pH} .4 .95$ ) and $37.5 \mathrm{ml}$. of distelled water.

Our materials consist of 45 cases of uterine cancers ; 39 cervical cancers and 6 cases of the uterine body. The majority of cervical cancers are squamous cell cancer, but 3 are adenocarcinoma. For control, 15 cases of normal stratified squamous epithlium of the cervix and 10 cases of normal endometriums were examined.

\section{Result}

$\beta$-glucuronidase activity was generally confined to the cytoplasm. The nuclei exhibited negative or weak reaction. In normal squamous epithelium of the cervix, 15 cases were examined.

The average degree of the staining intesity was graded 0 to $3 \mathrm{f}$. $\beta$-glucuronidase activity was observed from the basal layer to the stratum granulosum, the highest concentration of $\beta$-glucuronidase was seen in the stratum granulosum, less or weak activity was noted in the stratum corneum and weak activity was observed in the subepithelial tissues. (Fig. 1)

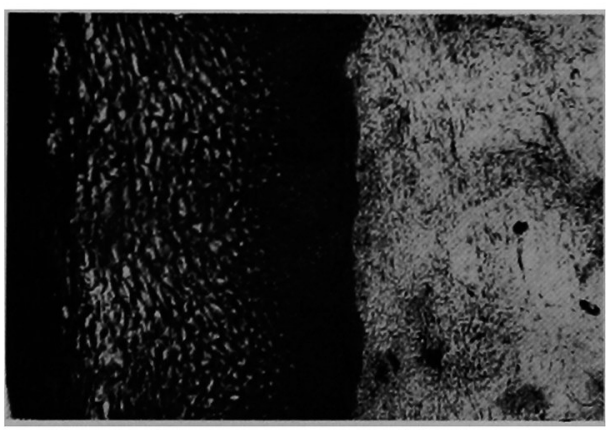

Fig. 1 Squamous cell epithelium showing high enzymatic activity in the st. granulosum. In other layers, moderate activity is observed. Subepithelial tissue is not reactive. $(\times 200)$

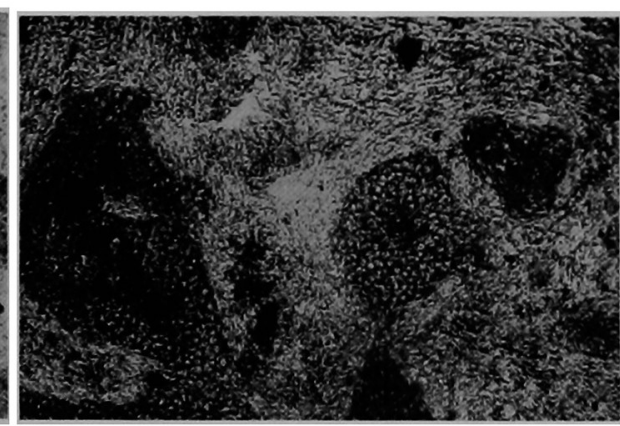

Fig. 2 Squamous cell carcinoma of the cervix Cancer cells show moderate or high enzymatic activity. Necrotic tissue, which is located in the center part of the cancer nest, is highly reactive. Stroma is not reactive. $(\times 80)$ 
In squamous cell carcinoma, intensity of the enzymatic activity of cancer cells were generally showed $1+$ to $3+$ reaction.

Strong enzymatic activity was observed in necrotic tissues, which were located in the center part of the some cancer nests. Intesity of the enzymatic

Table 1 Correlation between the enzymatic activity of the cancer tissue and clinical stage

\begin{tabular}{|c|c|c|c|}
\hline Stage & Activity & Cancer cells & stroma \\
\hline & 0 & 0 & 1 \\
\hline 0 & $1+$ & 0 & 0 \\
\hline \multirow[t]{2}{*}{1 case } & $2+$ & 0 & 0 \\
\hline & $3+$ & 1 & 0 \\
\hline & 0 & 0 & 1 \\
\hline I & $1+$ & 0 & 2 \\
\hline \multirow[t]{3}{*}{16 cases } & $2+$ & 12 & 13 \\
\hline & $3+$ & 4 & 0 \\
\hline & 0 & 0 & 2 \\
\hline II & $1+$ & 3 & 3 \\
\hline \multirow[t]{3}{*}{14 cases } & $2+$ & 8 & 9 \\
\hline & $3+$ & 3 & 0 \\
\hline & 0 & 0 & 1 \\
\hline III & $1+$ & 0 & 2 \\
\hline \multirow[t]{2}{*}{5 cases } & $2+$ & 4 & 2 \\
\hline & $3+$ & 1 & 0 \\
\hline
\end{tabular}

Table 2 Correlation between the enzymatic activity of the cancer tissue and frequeucy of delivery

\begin{tabular}{|c|c|c|c|}
\hline delivery & Activity & Cancer cells & stroma \\
\hline & 0 & 0 & 0 \\
\hline 0 & $1+$ & 1 & 0 \\
\hline \multirow[t]{2}{*}{2 cases } & $2+$ & 1 & 2 \\
\hline & $3+$ & 0 & 0 \\
\hline$\cdots-$ & 0 & 0 & 2 \\
\hline $1 \sim 3$ & $1+$ & 1 & 3 \\
\hline \multirow[t]{3}{*}{17 cases } & $2+$ & 12 & 1 \\
\hline & $3+$ & 4 & 1 \\
\hline & 0 & 0 & 3 \\
\hline $4 \sim 6$ & $1+$ & 2 & 1 \\
\hline \multirow[t]{2}{*}{12 cases } & $2+$ & 7 & 8 \\
\hline & $3+$ & 3 & 0 \\
\hline - & 0 & 0 & 1 \\
\hline $7 \sim$ & $1+$ & 0 & 3 \\
\hline \multirow[t]{2}{*}{5 cases } & $2+$ & 3 & 1 \\
\hline & $3+$ & 2 & 0 \\
\hline
\end{tabular}


activity of the stroma was showed 0 to $2+$. (Fig. 2)

Enzymatic activity of the stroma adjacent to the tumor cell was higher than that of the rest stroma. In the stroma where the round cells markedly infiltrated, intense enzymatic activity was observed.

1) Correlation between the enzymatic activity of the cancer tissue and the clinical stage of cervical cancer (Tab. 1).

2) Correlation between the enzymatic activity of the cancer tissue and the frequency of delivery (Tab. 2)

3) The enzymatic activity in comparison of the premenopausal case to the postmenopausal case. (Tab. 3)

Table 3 The enzymatic activity in comparison of the premeuopausal case to postmeuopausae case

\begin{tabular}{c|c|c|c} 
Period & Activity & Cancer cells & stroma \\
Premeuopausal case & 0 & 0 & 2 \\
(18 cases) & $1+$ & 1 & 5 \\
& $2+$ & 12 & 11 \\
& $3+$ & 5 & 0 \\
\hline Postmeuopausal case & 0 & 0 & 3 \\
(18 cases) & $1+$ & 2 & 11 \\
& $2+$ & 4 & 0 \\
\hline
\end{tabular}

10 cases of mormal endometrium were examined. Eive of these were postmenstrual endometrium and other five were premenstrual endometrium. $\boldsymbol{\beta}$-glucuronidase activity of the glandular and surface epithelium was higher than that of the squamous epithelium. Strroma cells of endometrium showed faint reaction. (Fig. 3)

Six cases of adencarcinoma of the uterine body and 3 cases of the cervix were examined. In adenocacinoma, enzymatic activity of cancer cells was higher than that of squamous cell cancers. (Fig. 4)

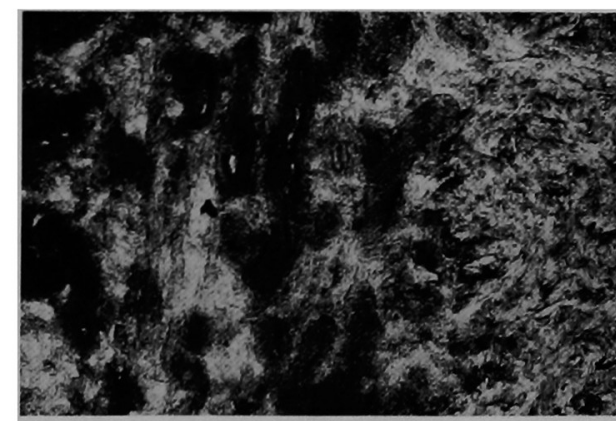

Fig. 3 Endometrium showing high enzy matic activity in the glandular epithelium. Stroma reacts negative of faint. $(\times 80)$

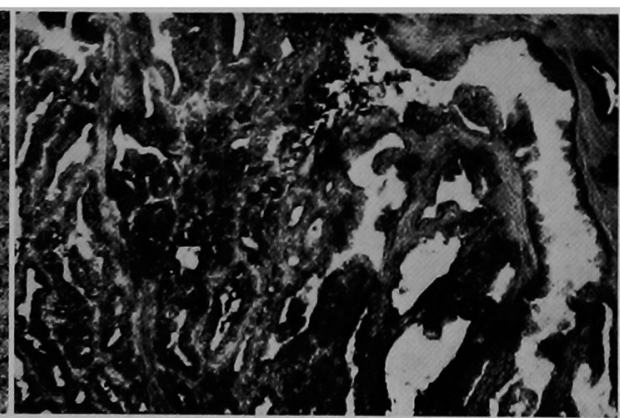

Fig. 4 Adenocarcinoma of the body $\mathrm{Ca}$ ncer cells have moderate or high enzymatic activity. Stroma cells is not reactive. $(\times 80)$ 


\section{Discussion}

We had observed histochemically $\beta$-glucuronidase activity in uterine cancers and normal tissues for control, utilizing 6-bromo-2-naphthyl- $\beta$-D-glucuronide as the substrate. The enzymatic activity was generally confined within the cytoplasm.

According to our observation, the cell of stratum granulosum showed intense enzymatic activity and were able to be distinguished from the rest of the epidermis where the activity was moderate. William Montagna had reported this point in 1956. Activity of glandular epithelium was higher than that of stratified squamous epithelium of the cervix, also Seligman et al. had reported this matter in 1954 . In our histochemical series, there was no difference between enzymatic pattern of postmenstrual endometrium and premenstrual endometrium.

Enzymatic activity of squamous cell cancer was higher than that of normal squamous epithelium which was considered as the homologous tissue of squamous cell cancer. Braun-Falco had reported in 1959 that intense enzymatic activity was observed in the cell element which were gathered by inflammation. His report agrees with our findings. According to our findings intense enzymatic activity was observed in the stroma, in which inflammatory cells were gathered densely.

But there were some cases, in which considerable enzymatic activity was observed in the stroma where few inflammatory cell were marked. This stromal enzymatic pattern was also observed in the distribution of leucine aminopeptidase which we had observed, but it was not clear in $\beta$-glucuronidase. In our series, enzymatic activity of cancer cell were not influenced by the clinical stage of cervical cancer and frequency of delivery. Our cases are not sufficient enough to discuss the correlation between enzymatic activity of cancer cell and its ripeness.

In adenocarcinoma of the body and cerix, intense enzymatic activity was observed. This enzymatic activity seems to be higher than that of endometrium. We could not observe any difference in enzymatic activity of $\beta$-glucuronidase under the influence of menstrual cycle, though some correlation between $\beta$ glucuronidase and steroid hormones had been discussed.

\section{Summary}

The histochemical observation of $\beta$-glucuronidase in 45 cases of uterine cancer was carried out in fresh frozen sections by Seligman's method, utilizing 6 -bromo-2-naphthyl- $\beta$-D-glucuronide as the substrate. In squamous cell carcinomas of the cervix, moderate enzymatic activity was observed in the cancer cells. This activity was higher than that of normal squamous epithelium. In adenocarcinoma of the body and the cervix, intense enzymatic activity was observed in the cancer. This was stronger than that of normal endometrium. The enzymatic activity of adenocarcinoma were generally higher than that of squamous cell cancers. Enzymatic activity in the stroma of cancer tissue was 
mainly slight. There were no correlation between enzymatic activity and the clinical stage of cervical cancer, and correlation between the enzymatic activity of the cancer tissue and frequency of delivery.

\title{
References
}

1) W. Montagna ; J. Biophysic. and Biochem. Cytol. Vol. 3 343-348 $1957 . \quad 2)$ J. S. Friedenwald and B. Becker; J. Cell. Comp. Physiol. 31 303-310 1948. 3) J. F. Burton and A. G. E. Pearse ; Brit. J. exp. Path. 33 87-97 1952. 4) A. M. Seligman, K. L. Tsou, S. H. Rutenberg and R. B. Cohen ; J. Histochem. and Cytochem. 2 209-228 $1954 . \quad 5)$ W. H. Fishman, J. R. Baker and P. R. F. Borgen ; Cancer. 12 240-245 $1959 . \quad$ 6) O. BraunFalco; Arch. klin. exp. Dermato. 203 68-72 $1956 . \quad 7)$ M. Izuo and K. Oota ; Jap. J. Cancer. Clin. 4 364-370 1958. 8) K. Oota and M. Izuo ; Jap. J. Cancer. clin. 4 356-363 1958. 9) K. Kawakatsu, M. Mori, M. Deguchiand M. Murakami ; J. Jap. stm. Soc. 9 261-267 1960. 10) M. Deguchi ; Arch. histo. japon. 21 41-60 1960. 11) A. Tabuchi, and K. Moriwaki ; Jap. J. Cancer. Clin. 3 806-811 1957. 12) T. Tanase ; IGAKU NO AYUMI. 42 232-236 1962. 13) N. Sinagawa, S. Morita and S. watanabe. Jap. J. Caneer. clin. 5 579-583 1950.

\section{Histochemical Studies on the Regenerated Adrenal Cortex ${ }^{*}$}

\author{
Ryuei Maeda, Reiko Takada, Ichiro Yamagata \\ and Tatsuji Hagrhara
}

The First Department of Pathology (Prof. R. Maeda), Kansai Medical School, Osaka, Japan

* Aided by the Grant in Aid for Fundamental Scientific Research of the Ministry of Education

In a preceding paper ${ }^{6)}$ the assumption that the sudanophilic granules in paraffin section of rat adrenals fixed with Tellyesniczky's fluid contain corticoids, has been proven to be supported by a successful extraction of corticoids from sudanophilic components of bovine adrenals, or of corticoids administered in the subcutaneous tissues of rats fixed with Tllyesniczky's fluid.

Much has been discussed ${ }^{7)}$ on the significant role of enzymes in the formation of corticoids from cholesterol in the adrenal cortex. An attention has been directed on the relationship between endocrinological function of the adrenal cortex and enzymic action. While the reports on adrenal enucleation have been made a number of times ${ }^{2}$, hardly any on the histochemical study on the enzymes especially of oxidative enzymes in regenerated adrenocortical tissue. To test these enzymes, the present investigation is concerned with the active regenerating cortical cells and combined with the staining method of Heidenhain iron hematoxylin Sudan. ${ }^{\text {s) }}$ 